\title{
Prokaryotic triterpenoids
}

\section{A novel hopanoid from the ethanol-producing bacterium Zymomonas mobilis}

\author{
Gérard FLESCH and Michel ROHMER* \\ Ecole Nationale Supérieure de Chimie de Mulhouse, 3 rue Alfred Werner, 68093 Mulhouse Cedex, France
}

\begin{abstract}
Among the triterpenoids of the bacterium Zymomonas mobilis a novel hopanoid, 32-oxobacteriohopane$33,34,35$-triol $\beta$-linked via its primary hydroxy group to glucosamine, has been isolated as a minor compound.
\end{abstract}

\section{INTRODUCTION}

Hopanoids belong to a triterpene series widespread among prokaryotes. In these micro-organisms they play the role of membrane stabilizers played by sterols in eukaryotes [1,2]. Various $\mathbf{C}_{30}$ olefins of the hopane series (VII, Fig. 1) as well as diplopterol (II) have been reported from the ethanol-producing bacterium Zymomonas mobilis $[3,4]$. However, the major compounds are $C_{35}$ bacteriohopane derivatives which have been found to be always predominant in all hopanoid-producing bacteria analysed so far [1]. Thus, in addition to small amounts of diploptene (I) (about $0.2 \mathrm{mg} / \mathrm{g}$ dry wt.), diplopterol (II) $(0.8 \mathrm{mg} / \mathrm{g})$ and bacteriohopanetetrol (III) $(1 \mathrm{mg} / \mathrm{g})$, we could identify the bacteriohopanetetrol ether (IV) (1.7 $\mathrm{mg} / \mathrm{g})$ and the glycoside $(\mathrm{V})(2.5 \mathrm{mg} / \mathrm{g})$ by comparison with the hopanoids isolated from the facultative methylotroph Methylobacterium organophilum $[5,6]$. The structure of the ether (IV) was corrected independently, and at a later point, by Barrow's group [7].

In several cultures glycoside (V) was accompanied by a novel minor hopanoid (VI), which could be isolated by reverse-phase h.p.l.c. and whose structure is reported here.

\section{MATERIALS AND METHODS}

\section{General methods}

Zymomonas mobilis (A.T.C.C. 29191) was grown under microaerophilic conditions in batch cultures in a 200litre fermenter as previously described [8]. Hopanoids (I-V) were isolated as acetylated derivatives and analysed as previously described [6,9]. The new glycoside (VI) accompanied hopanoid (V) in all t.l.c. separations. It could be separated from its companion by reversephase h.p.l.c. on a Waters $C_{18} \mu$ Bondapak column $(300 \mathrm{~mm} \times 3.9 \mathrm{~mm})$ by using methanol/water $(24: 1, \mathrm{v} / \mathrm{v}$; $1 \mathrm{ml} / \mathrm{min}$ ) as eluent and a Spectra Physics SP6440 differential refractometer as detector.

\section{Hexa-acetate of glycoside (VI)}

The ${ }^{1} \mathrm{H}$-n.m.r. [400 MHz, $\left({ }^{2} \mathrm{H}\right)$ chloroform] characteristics were as follows: $\delta$ (p.p.m.) 0.701 (3H, s, 18 $\alpha$ $\left.\left.\mathrm{CH}_{3}\right), 0.797\left(3 \mathrm{H}, \mathrm{s}, 4 \beta-\mathrm{CH}_{3}\right), 0.8193 \mathrm{H}, \mathrm{s}, 10 \beta-\mathrm{CH}_{3}\right)$, $0.852\left(3 \mathrm{H}, \mathrm{s}, 4 \alpha-\mathrm{CH}_{3}\right), 0.936\left(3 \mathrm{H}, \mathrm{d}, J 6.5 \mathrm{~Hz}, 22 R-\mathrm{CH}_{3}\right)$, $0.953\left(6 \mathrm{H}, \mathrm{s}, 8 \beta\right.$ - and $\left.14 \alpha-\mathrm{CH}_{3}\right), 1.982\left(3 \mathrm{H}, \mathrm{s}, \mathrm{CH}_{3} \mathrm{CONH}\right)$, $2.032\left(6 \mathrm{H}, \mathrm{s}, 2 \mathrm{CH}_{3} \mathrm{CO}_{2}^{-}\right), 2.082\left(3 \mathrm{H}, \mathrm{s}, \mathrm{CH}_{3} \mathrm{CO}_{2^{-}}\right)$, $2.102\left(3 \mathrm{H}, \mathrm{s}, \mathrm{CH}_{3} \mathrm{CO}_{2^{-}}\right), 2.182\left(3 \mathrm{H}, \mathrm{s}, \mathrm{CH}_{3} \mathrm{CO}_{2}^{-}\right), 2.46$ $(2 \mathrm{H}, \mathrm{m}, 31-\mathrm{H}), 3.70\left(2 \mathrm{H}, \mathrm{m}+\mathrm{dd}, J_{34,35 \mathrm{a}} 6.5 \mathrm{~Hz}, J_{35 \mathrm{a}, 35 \mathrm{~b}}\right.$ $11.0 \mathrm{~Hz}, 5^{\prime}-\mathrm{H}$ and $\left.35-\mathrm{H}_{\mathrm{a}}\right), 3.76\left(1 \mathrm{H}, \mathrm{dt}, J_{1^{\prime}, 2^{\prime}}=J_{2^{\prime}, \mathrm{NH}}\right.$ $\left.8 \mathrm{~Hz}, J_{2^{\prime}, 3^{\prime}} 10 \mathrm{~Hz}, 2^{\prime}-\mathrm{H}\right), 3.97\left(1 \mathrm{H}, \mathrm{dd}, J_{34,35 \mathrm{~b}} 6.5 \mathrm{~Hz}, J_{35 a, 35 b}\right.$ $\left.11 \mathrm{~Hz}, 35-\mathrm{H}_{\mathrm{b}}\right), 4.12\left(1 \mathrm{H}, \mathrm{dd}, J_{5^{\prime}, 6^{\prime} \mathrm{a}} 2 \mathrm{~Hz}, J_{6^{\prime} \mathrm{a}, 6^{\prime} \mathrm{b}} 12 \mathrm{~Hz}, 6^{\prime}-\right.$ $\left.\mathrm{H}_{\mathrm{a}}\right), 4.27\left(1 \mathrm{H}, \mathrm{dd}, J_{5^{\prime}, 6^{\prime} \mathrm{b}} 4.5 \mathrm{~Hz}, J_{6^{\prime} \mathrm{a}, 6^{\prime} \mathrm{b}} 12 \mathrm{~Hz}, 6^{\prime}-\mathrm{H}_{\mathrm{b}}\right), 4.69$ (1H, d, $\left.J_{1^{\prime}, 2^{\prime}} 8.5 \mathrm{~Hz}, 1^{\prime}-\mathrm{H}\right), 5.07\left(1 \mathrm{H}, \mathrm{t}, J_{3^{\prime}, 4^{\prime}}=J_{4^{\prime}, 5^{\prime}} 10 \mathrm{~Hz}\right.$, $\left.4^{\prime}-\mathrm{H}\right), 5.29\left(1 \mathrm{H}, \mathrm{d}, J_{33,34} 3.5 \mathrm{~Hz}, 33-\mathrm{H}\right), 5.46\left(1 \mathrm{H}, \mathrm{dt}, J_{33,34}\right.$ $\left.3.5 \mathrm{~Hz}, J_{34,35 \mathrm{a}}=J_{34,35 \mathrm{~b}} 7 \mathrm{~Hz}, 34-\mathrm{H}\right), 5.59\left(1 \mathrm{H}, \mathrm{d}, J_{2^{\prime}, \mathrm{NH}}^{33,34}\right.$ $8 \mathrm{~Hz}$, -NH-, exchangeable with ${ }^{2} \mathrm{H}_{2} \mathrm{O}$ ).

The mass spectrum (direct inlet, $70 \mathrm{eV}$ ) characteristics were as follows: $m / z=957\left(M^{+}, 0.4 \%\right), 898\left(M^{+}\right.$ $\mathrm{AcNH}_{2}, 0.2 \%$ ), 736 (ring $\mathrm{C}$ cleavage [10], $0.1 \%$ ), 611 (cleavage of the glycosidic bond between $\mathrm{C}-1^{\prime}$ and oxygen at $\mathrm{C}-35,8 \%$ ), 595 (cleavage of the glycosidic bond between C-35 and oxygen at C-35, $0.8 \%), 550(2 \%), 508$ $(4 \%), 369\left(M^{+}-\right.$side chain, 5\%), $337(100 \%), 336$ $(87 \%), 335(87 \%), 330$ (cleavage of the glycosidic bond between C-1' and oxygen at C-35, $93 \%), 320(70 \%), 241$ $(67 \%), 210(50 \%), 191$ (ring C cleavage [10], 53\%).

The mass spectrum (chemical ionization using $\mathrm{NH}_{3}$ as reactant gas) characteristics were as follows: $m / z=975$ $\left(M+\mathrm{NH}_{4}^{+}\right), 958\left(M+\mathrm{H}^{+}\right)$.

\section{RESULTS AND DISCUSSION}

In some Zymomonas mobilis cultures the bacteriohopanetetrol glycoside (V) was accompanied by a minor compound (VI) representing maximally $5 \%$ of the glycoside fraction. After acetylation this compound could not be isolated by t.l.c., but careful separation by reversephase h.p.l.c. yielded small amounts $(1.5 \mathrm{mg}$ from $40 \mathrm{~g}$ of freeze-dried cells) that were sufficient for structural elucidation by spectroscopic methods.

The ${ }^{1} \mathrm{H}$-n.m.r. spectrum $(400 \mathrm{MHz})$ was characteristic of a hopanoid glycoside structure [6,9]. Indeed, on the one hand all methyl singlets as well as the doublet at $\delta=$ 0.936 p.p.m. corresponded to the signals of bacteriohopane derivatives. On the other hand, seven signals each corresponding to one proton showed chemical shifts, multiplicities and coupling constants identical with (or sometimes in the case of chemical shifts similar to) those of the acetylated glucosamine moiety of glycoside (V) $[6,9]$. The coupling constants of vicinal protons were of the order of magnitude of $10 \mathrm{~Hz}$, indicating a chair 
<smiles>C=C(C)C1CCC(C)(C)C1C</smiles>

(I)<smiles>CC(CC[C@@H](O)[C@@H](O)[C@H](O)CO)C1CC[C@@]2(I)CCC12</smiles>

(III)<smiles>CC(CCC(O)[C@@H](O)[C@@H](O)COC1C(N)C(O)C(O)C1(O)CO)C1CCC(C)(C)C1C</smiles><smiles>CC(CC[C@@H](O)[C@@H](O)[C@@H](O)COC1OC(CO)C(O)C(O)[C@H]1N)C1CCC(C)(C)C1C</smiles><smiles>CC(CCC(=O)C(O)C(O)CO[C]1O[C@H](CO)[C@@H](O)[C@H](O)[C@H]1N)C1CCC(C)(C)C1C</smiles>

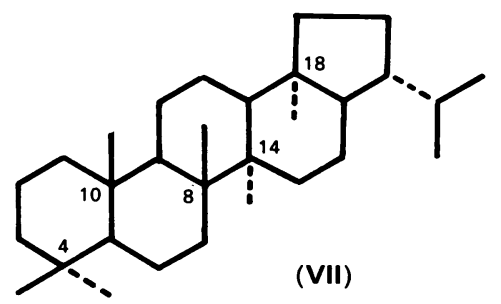

Fig. 1. Hopanoids from Zymomonas mobilis (I-VI)

Compound (VII) is hopane.

conformation of the hexose and an axial position for all these protons, thereby suggesting the stereochemistry of a $\beta$-glycoside of glucosamine. The presence of this structural feature was further confirmed by homonuclear ${ }^{1} \mathrm{H} /{ }^{1} \mathrm{H}$ correlation spectroscopy (COSY) and by decoupling experiments. The absolute configuration of this glucosamine moiety was not determined, but we assumed that this hexose belonged to the D-series by analogy with the bacteriohopanetetrol glycoside isolated by Langworthy et al. [11] from Bacillus acidocaldarius.
The structure of the bacteriohopane moiety could be determined from the homonuclear ${ }^{1} \mathrm{H} /{ }^{1} \mathrm{H}$ COSY spectrum. Indeed, four signals each corresponding to one proton were relevant to the following sequence. Two doublets at $\delta 3.70$ and 3.97 p.p.m. corresponded to two vicinal protons coupled one to each other $(J 11 \mathrm{~Hz})$ and to another proton $(J 7 \mathrm{~Hz})$ characterized by a doublet of triplets at $\delta 5.47$ p.p.m. This latter proton is also coupled with a proton $(J 3 \mathrm{~Hz})$ whose signal was a doublet at $\delta$ 5.29 p.p.m. and which was consequently not coupled with another proton. These protons might therefore be located on C-35, C-34 and C-33, C-32 bearing no proton and corresponding thus most probably to a carbonyl group. Indeed, the presence of a ketone carbonyl group was suggested by the presence on the one hand of a shoulder at $1710 \mathrm{~cm}^{-1}$ in the i.r. spectrum next to the strong band at $1740 \mathrm{~cm}^{-1}$ of the five acetoxy carbonyl groups and, on the other hand, of the multiplet at $\delta 2.46$ p.p.m. in the ${ }^{1} \mathrm{H}-$ n.m.r. spectrum of the two C-31 protons which are in an $\alpha$-position to the $\mathrm{C}-32$ carbonyl group and which are only coupled with the $\mathrm{C}-30$ protons at $\delta$ 1.7 p.p.m. according to the two-dimensional ${ }^{1} \mathrm{H} /{ }^{1} \mathrm{H}$ correlation. The presence of one amino and five hydroxy groups was further confirmed by the six methyl singlets from acetyl groups in the 2 p.p.m. region of the ${ }^{1} \mathbf{H}$ n.m.r. spectrum.

The structure deduced from the preceding data is thus in accordance with a $\beta$-glycoside of 32-oxobacteriohopane-33,34,35-triol. As the chemical shifts of the C-35 protons ( $\delta 3.70$ and 3.97 p.p.m.) were similar to those of the corresponding protons of acetylated glycoside $(\mathbf{V})(\delta$ 3.87 p.p.m.) and were definitely different from those of the tetra-acetate of bacteriohopanetetrol (III) $(\delta 4.15$ and 4.39 p.p.m.) [6], it seemed reasonable to assume that the C-35 hydroxy group was involved in the formation of the glycosidic bond.

Mass spectrometry performed on the hexa-acetate of (VI) was in full accordance with the structure proposed for this new glycoside. Indeed the molecular ion obtained after electron impact $(m / z=957)$ was consistent with the required molecular formula. Confirmation of the molecular mass was further obtained by chemical ionization using ammonia as reactant gas and showing ions at $\mathrm{m} / \mathrm{z}$ $975\left(M+\mathrm{NH}_{4}^{+}\right)$and $958\left(M+\mathrm{H}^{+}\right)$. All other fragmentations were consistent with those usually observed for the bacteriohopane skeleton and for the presence of the glycosidic bond [6].

This new hopanoid isolated from Zymomonas mobilis is the first one possessing an oxo group on the bacteriohopane side chain. Ir remains now to be determined whether it is a precursor or a catabolite of bacteriohopanetetrol, since nothing is known about the metabolism of this widespread bacterial polyterpenoid, which is responsible for the tolerance of Zymomonas mobilis to high osmotic pressures and ethanol concentrations $[8,12]$.

We thank Professor K. Poralla (Universität Tübingen, Tübingen, Federal Republic of Germany) for the gift of freezedried Zymomonas mobilis cells, and Mrs. E. Krempp (Département de Chimie, Université Louis Pasteur, Strasbourg, France) for all n.m.r. measurements. This work was partly supported by the Centre National de la Recherche Scientifique (Unité de Recherche Associée 135) and by a grant from the Ministère de l'Education Nationale (Réseau Européen de Laboratoires 1987) 


\section{REFERENCES}

1. Rohmer, M., Bouvier-Navé, P. \& Ourisson, G. (1984) J. Gen. Microbiol. 130, 1137-1150

2. Ourisson, G., Rohmer, M. \& Poralla, K. (1987) Annu. Rev. Microbiol. 41, 301-333

3. Tornabene, T. G., Holzer, G., Bittner, A. S. \& Grohmann, K. (1982) Can. J. Microbiol. 28, 1107-1118

4. Barrow, K. D., Collins, J. G., Rogers, P. L. \& Smith, G. M. Biochim. Biophys. Acta 324, 324-330

5. Flesch, G. (1987) Ph.D. Thesis, Université de Haute Alsace, Mulhouse, France

6. Renoux, J. M. \& Rohmer, M. (1985) Eur. J. Biochem. 151, 405-410

Received 15 June 1989; accepted 4 July 1989
7. Smith, G. L. (1985) Ph.D. Thesis, University of New South Wales, Sydney, Australia

8. Bringer, S., Härtner, T., Poralla, K. \& Sahm, H. (1985) Arch. Microbiol. 140, 312-316

9. Neunlist, S., Bisseret, P. \& Rohmer, M. (1988) Eur. J. Biochem. 171, 245-252

10. Budzikiewicz, H., Wilson, J. \& Djerassi, C. (1963) J. Am. Chem. Soc. 85, 3688-3699

11. Langworthy, T. A., Mayberry, W. R. \& Smith, P. F. (1976) Biochim. Biophys. Acta 431, 570-577

12. Schmidt, A., Bringer-Meyer, S., Poralla, K. \& Sahm, H. (1986) Appl. Microbiol. Biotechnol. 25, 32-36 